\title{
Arkeolojik Buluntuların Sergilenmesi ve Korunmasında Yeni Yaklaşımlar
}

\author{
Özgü ÖZTURAN D1 1, Büşra GÖKÜZ DiD 1, Zuhal KAYNAKCI ELINÇ (iD)* \\ ${ }^{1}$ Akdeniz Üniversitesi, Mimarlık Fakültesi, Antalya \\ Geliş Tarihi (Received): 11.11.2020, Kabul Tarihi (Accepted): 13.12.2020 \\ $\square$ Sorumlu Yazar (Corresponding author*): zuhalelinc@akdeniz.edu.tr \\ (C) +902422274480 동 +902423106213
}

$\overline{\text { ÖZ }}$

Antik kentlerin arkeolojik sit alanı ilan edilmesiyle bu bölgeler koruma altına alınmıştır. Arkeolojik alanlarda kazılar sırasında ortaya çıkarılan değerli buluntular, taşınabilir olduklarında müzelerde hem sergilenip hem de koruma altına alınmaktadır ancak mimari buluntuların yerinde korunması gerekmektedir. Arkeolojik alanlarda kazılar sonucu ortaya çıkartılan mimari eserlerin bir süre sonra olumsuz çevresel etkenlerden korunması intiyacı doğmaktadır. Kent içi arkeolojik sit alanları, zamanla kentte değer verilmeyen atıl alanlara dönüşmektedir. Bu arkeolojik alanların kent içindeki varıklarına devam etmesi kültürel mirasın korunması açısından çok önemlidir. Ülkemizde inşaat temeli kazıları sırasında arkeolojik kalıntılara son yıllarda özellikle de çok katmanlı yerleşimlere sahip illerde sıklıkla rastlanılmaktadır. Bu çalışmada; ülkemizde Hatay ve Antalya illerinde ortaya çıkan iki büyük arkeolojik kalıntılar ve sonrasında korunması için yapılan mimari yapılar ele alınmıştır. İnşa sırasında ortaya çıkan arkeolojik kalıntılar sonucunda bu alanlara yapılacak projeler tamamen değişerek hem arkeolojik kalıntılar koruma altına alınmış hem de ek bir işlev eklenerek yapıların kent yaşantısı ile bütünleştirilmesi hedeflenmiştir. Ayrıca pek çok otorite tarafından iyi bir örnek olarak gösterilen arkeolojik kalıntıların üzerine inşa edilen Atina Yeni Akropol Müzesi de çalışmaya dahil edilmiştir. Bu çalışma üç aşamalı olarak yürütülmüştür. Antakya Müze Oteli ile Antalya Nekropol Alanı Kültür ve Ticaret Merkezi arkeolojik alanlarda koruyucu yapılar için tasarım kriterleri irdelenerek ele alınmıştır.

Anahtar Kelimeler: Arkeolojik alan, arkeolojik sit alanı, ek işlev, kent içi arkeolojik kalıntılar, kültürel miras

\section{New Approaches for Exhibiting and Protecting Archeological Findings}

\begin{abstract}
Ancient cities are taken under protection by declaring them archaeological protected sites. Valuable findings discovered in archaeological excavations, which can be moved are exhibited and protected in museums, while architectural findings should be protected where they are discovered. After a while, it becomes necessary to protect architectural artefacts discovered as a result of excavations in archaeological sites against adverse environmental factors. Archaeological protected sites inside cities become unappreciated passive sites of these cities. Concerning protecting cultural heritage, it is very important to continue the existence of these archaeological protected sites inside cities. In our country, archaeological remains are frequently encountered in recent years, especially in provinces with multilayered settlements during construction foundation excavations. In this study, two large-scale archaeological remains found in the provinces of Hatay and Antalya and architectural structures constructed for protecting them are addressed. In consequence of the archaeological remains found during constructions, the projects to be established these places have completely changed and the archaeological remains are taken under protection and it is intended to integrate these remains with the life of the city by including an additional function. Furthermore, the Athens New Acropolis Museum built on these archaeological remains, indicated as a good example by several authorities have been included in the project. This project has been carried out in three phases. Antakya Museum Hotel and the Antalya


Necropolis Site Culture and Trade Center have been taken into consideration by examining design criteria for protective structures in archaeological protected sites.

Keywords: Archaeological site, archaeological protected site, additional function, archaeological remains inside cities, cultural heritage

\section{GíRiş}

Arkeolojik sit, Kültür ve Tabiat Varlıklarını Koruma Yüksek Kurulu'nun ilke kararında "İnsanlığın varoluşundan günümüze kadar ulaşan eski uygarlıkların yer altında, yer üstünde ve su altındaki ürünleri, yaşadıkları devrin sosyal, ekonomik ve kültürel özelliklerini yansıtan her türlü kültür varlığının yer aldığı yerleşmeler ve alanlar" olarak tanımlaması yapılmıştır (Madran ve Özgönül, 2011). Arkeolojik sitlerde, geçmişte yaşamış uygarlıklara ait farklı fonksiyonlara sahip mimari kalıntılar bulunmaktadır. Ortaya çıkan kalıntılar tek bir yapı, bir kompleks, antik kentin bir bölümü veya bütününe ait olabilmektedirler. Farklı fonksiyonlara sahip bu kalıntılar bir ya da birden çok döneme tanıklık etmiş olabilmektedirler (Şener, 2013).

II. Dünya Savaşı sonrasında kentsel arkeoloji kavramının ortaya çıkmıştır. Savaşın başlamasıyla birlikte pek çok Avrupa kentinde yıkımlar olmuştur. Savaş sonrasında kentlerde kültürel mirasın tahrip olmuş haliyle karşı karşıya kalınmış ve kentlerin önceki dönemlerine ait kalıntılar ortaya çıkmıştır. Bu durum ortaya çıkan kaIıntıların araştırılmaya başlamasını sağlamıştır (Sarfatij ve Melli, 1999).

Kent içinde bulunan ve ortaya çıkmamış olan arkeolojik alanlar yeni yapılaşmaların temel kazıları sırasında ortaya çıkabilmektedirler. Bu durumda mimari proje ile arkeolojik alan karşı karşıya gelmektedir. Arkeolojik buluntuların ortaya çıkması mimari projenin yapılmasını engelleyen bir etken olarak görülmektedir. Aslında ikisi birbirine entegre olup, ortaya birbirini besleyen bir sonuç çıkabilir. Ortaya çıkan bu arkeolojik alanlar, doğru bir planlamayla modern yaşama dahil olabilirler. Kent kullanıcısı da kent belleğini oluşturduğu düşüncesiyle arkeolojik alanları benimsenip bu alanların korunmasında katkı sağlayabilir (Savrum-Kortanoğlu, 2007). Kent içi arkeolojik sit alanlarında gelişim devam ettiği ve bir yandan da yaşam sürdürüldüğü için arkeolojik buluntuların korunması kırsal arkeolojik alanlara göre daha zor olmaktadır.

ICOMOS (Uluslararası Anıtlar ve Sitler Konseyi) Kültürel Miras Alanların Algılanması ve Sunumu Tüzüğü (2008)'ne göre sunuma yönelik çalışmalarda, kültürel miras alanlarında bulunan kalıntılara zarar veren uygulamalardan kaçınılması gerektiği belirtilmiştir. Alanda bulunacak olan bilgilendirme levhaları ve yürüyüş yolları tasarlanırken alanın asıl öznesi olan kültürel değerinin önüne geçmeyecek şekilde olmasına dikkat edilmelidir. Bu alanlarda yapılacak gösteri, konser gibi etkinliklerde alanın tahrip edilmesinin önüne geçilmelidir.

Kentsel arkeolojik mirasın korunması, kent kimliğinin oluşturulması ve kültürel katmanların algılanması için önemli bir yere sahiptir. Ancak kentsel arkeolojik alanların korunmasında birçok sorunla karşılaşılmaktadır. Kentlerde çağa yetişme kaygısıyla kontrol edilemeyen kentsel gelişmeler ile hem yer altındaki hem de yer üstündeki kentsel arkeolojik alanlar tahrip olmaktadırlar. Kent içi arkeolojik alanlar ile kırsal arkeolojik alanlar çoğu zaman aynı yöntemlerle korunmaya çalışıımıştır. Bu durum kent içinde tanımsız çöküntü alanları oluşmasına sebep olmuş ve arkeolojik alanlar zarar görmüştür. Kent içi arkeolojik alanlar, kültürel miras olarak algılanması gerekirken, kentsel gelişmeyi engelleyen alanlar olarak görülmüştür. Bu düşünce, kent içi arkeolojik alanların kültürel birikimi yansıtmaktan uzak; modern gereksinimlere yanıt veremeyen ve kentsel olanaklardan yararlanamayan alanlar olarak algılanmasına sebep olmuştur (Yıkıcı, 2010).

Türkiye'de ortaya çıkan arkeolojik alanların kent kimliğinin oluşturulması ve kültürel bir öge olarak algılanmasıyla ilgili çalışmaların bulunmadığı örnekler de gözlemlenmiştir. Ankara Altındağ İlçesi Ulus mevkiinde bulunan antik roma tiyatrosunun kent kullanıcısıyla entegre hale gelmesi için hiçbir çaba içine girilmemiştir. Ayrıca mimari buluntunun çevresel etkenlerden korunması için üst örtü sistemi geliştirilmemiştir.

Arkeolojik alanın çevresinin tellerle çevrili olmasına rağmen, kent kullanıcılarının bu alana çöplerini bırakmalarının ve alanda bulunan taşlara zarar vermelerinin önüne geçilememiştir. Ayrıca arkeolojik alan evsiz insanların sığınak amaçlı kullanımıyla tahrip edilmeye devam etmektedir (Demirdağ, 2017). Kente ve kentlinin yaşamına katılmadığı için kentten kopuk niteliksiz bir alan halini almıştır (Şekil 1). 

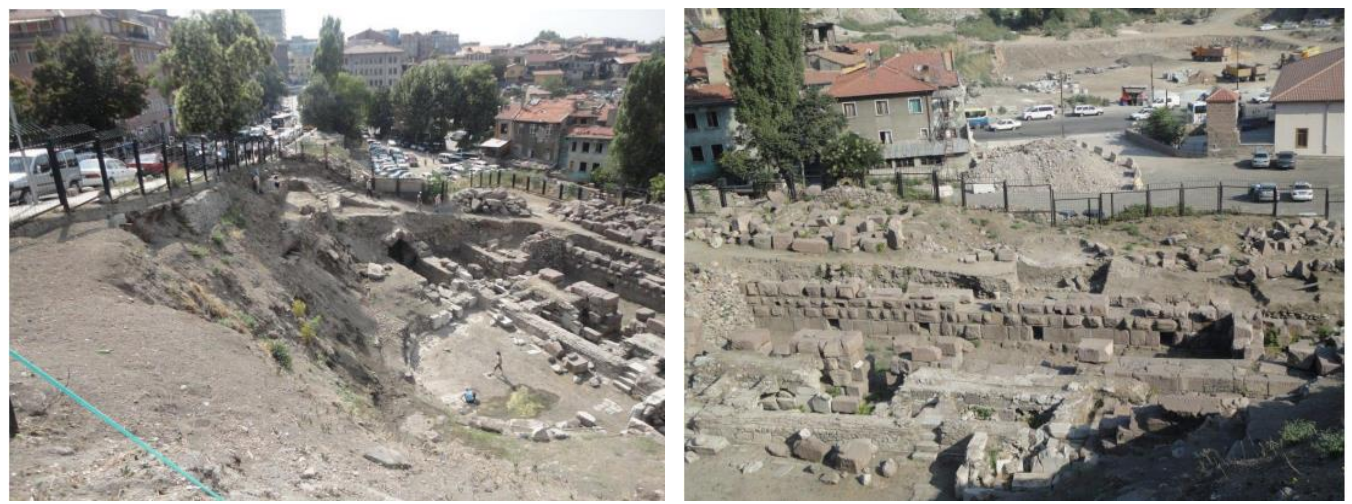

Şekil 1. Antik roma tiyatrosu ve çevreyle ilişkisi (Demirdağ, 2017)

Kentsel arkeolojik alanların korunmasında birçok sorunla karşılaşıldığı gözlemlenmektedir. Kent içinde yapılaşma tehdidi ile karşı karşıya kalan arkeolojik alanlar ortaya çıkmaktadır. Kentsel arkeolojik alanlar, zamanla kentten kopuk niteliksiz alanlara dönüşmektedir. Bu arkeolojik alanların kent içindeki varlıklarına devam etmesi gerekmektedir. Bu anlamda dünyadan Atina Yeni Akropol Müzesi; ülkemizden Antakya Müze Oteli ile Antalya Nekropol Alanı Kültür ve Ticaret Merkezi bu sorunlara yeni bir yaklaşımla çözüm aradığı için incelenmiştir.

\section{MATERYAL VE YÖNTEM}

Çalışmada materyal olarak kent içinde bulunan üç mekan seçilmiştir. Bu mekanlar; Atina Yeni Akropol Müzesi, Antakya Müze Oteli, Antalya Nekropol Alanı Kültür ve Ticaret Merkezi'dir. Bu üç yapının ortak özelliği; 2000 yılından sonra yapılmış olması, aynı iklim kuşağında bulunması, arkeolojik kalıntıların inşaat sırasında ortaya çıkması ve projelerinin arkeolojik kalıntılara göre değiştirilerek uygulanmasıdır.

Atina Akropol eserlerinin bir müzede sergilenmesi ilk olarak 1865 'te Kutsal Kaya üzerinde bulunan yap ile başlamıştır. 1885 'ten sonra ortaya yeni buluntuların çıkmasıyla ikinci bir müze yapısı ihtiyacı ortaya çıkmıştır. Bu ihtiyaç, günümüzde "Küçük Akropol Müzesi” olarak bilinen yapının yapılmasını sağlamıştır. Daha sonraki süreçte, Akropol Eserlerinin Restorasyonu Komitesi Akropol'den alınarak Ingiltere'ye taşınan eserlerin geri alınması kararını almıştır. Bu karar ile tekrardan sergileme alanlarına intiyaç duyulmasına sebep olmuştur. Yeni müze, pek çok mimari yarışmayla 34 yıl gibi uzun bir sürenin sonunda inşa edilebilmiştir (Akkurt, 2010).
Yeni müzenin nerede konumlanması gerektiği birçok tartışmanın ortaya çıkmasına sebep olmuştur. Tartışmalar sonucunda yeni müzenin Akropol'ün güneydoğu yamaçlarında bulunan Makriyianni bölgesinde konumlandırılmasına karar verilmiştir. 1975 ve 1979'da Yeni Akropol Müzesi için mimari yarışmalar düzenlenmiş, ancak bu yarışmalardan bir sonuca ulaşılamamıştır. 1989'da üçüncü kez yarışma düzenlemiştir. Ancak Makriyianni alanında kazılarda ortaya çıkan yeni buluntular, yarışmayı kazanan projeyi uygulanamaz hale getirmiştir. Dördüncü yarışma ise 2000 yılında düzenlenmiştir. Bu yarışmanın şartnamesinde proje alanında devam etmekte olan arkeolojik kazıların müzeye dâhil edilmesi şartı bulunmaktadır. Yarışma sonucunda Tchumi Architects'in projesi seçilmiş, Yeni Akropol Müzesi'nin 2004'te inşası başlamış ve açııışı 20 Haziran 2009 tarihinde yapılmıştır (Akkurt, 2010). Müze, her bir bölümünün programın ihtiyaçlarına göre birbirine eklemlenmiş bir taban, orta ve üst kısım olarak tasarlanmıştır (Şekil 2). Müzenin tabanı alanında uzmanlar kişiler tarafından yerleştirilmiş sütun ağı ile mevcut arkeolojik kazılar korunmaktadır. Orta seviyede giriş lobisinin yanı sıra geçici sergi alanları ve bir oditoryum bulunmaktadır. Arkeolojik kazılara bakan cam bir rampa, uzun sütunlarla desteklenerek ortadaki galerilere açılmaktadır (Şekil 3). Bir kapalı avlu etrafında düzenlenmiş dikdörtgen Parthenon Galerisi'nden oluşan üst kısım ise Frizin mermerlerini yüzyıllar önce olduğu gibi tam olarak yönlendirmek için Parthenon'a dönmüştür. Şeffaf Parthenon Galerisi, Akropolis'e doğrudan bakmak için en ideal ışığı sağlamıştır (URL-1, 2020). 


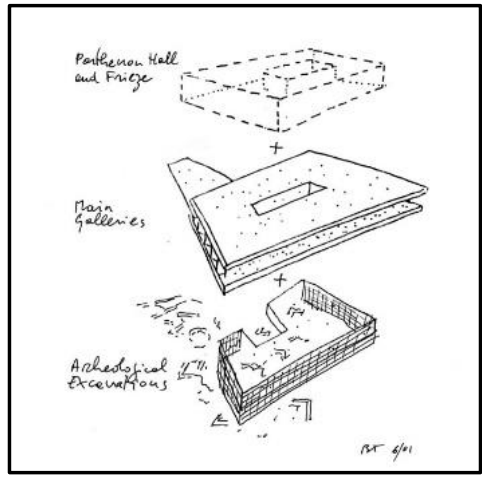

Şekil 2. Müzenin taban, orta ve üst bölümleri (URL-9, 2020)

Dolaşım aksı, şehrin sokaklarından farklı dönemlere ait arkeolojik kalıntıların bulunduğu tarihi dünyaya götüren mekân deneyimi sağlamaktadır (Şekil 4). Ziyaretçinin müze içindeki rotası ile bir döngü oluşturularak arkeolojik kazılardan uzanan mimari ve tarihi bir gezinti yeri sağlayıp, ziyaretçiler Roma dönemine geri döndürülmüştür (URL-1, 2020).

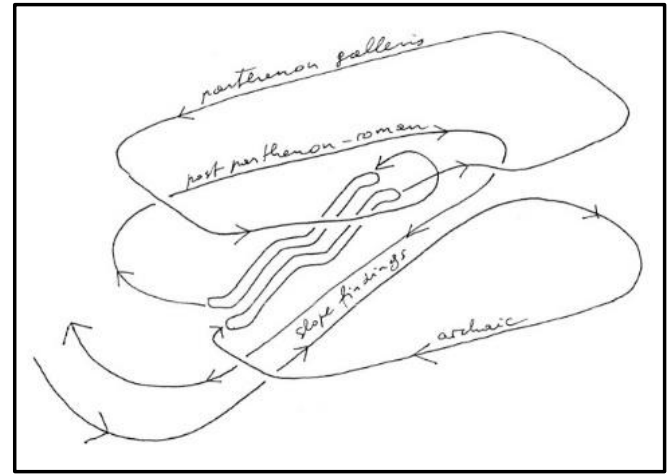

Şekil 3. Sergi kurgusu (URL-9, 2020)

Arkeolojik buluntular, MÖ 4. yy'dan 12. yy'a kadar yaşanmışıkları göz önüne sermektedir. Arkeolojik kalıntılar içerisinde sokaklar, konutlar, hamamlar, atölyeler ve mezarlar bulunmaktadır (Şekil 5-8). Kalıntıların arasında en iyi korunanlar geç antik döneme ait olanlardır (URL2, 2020).

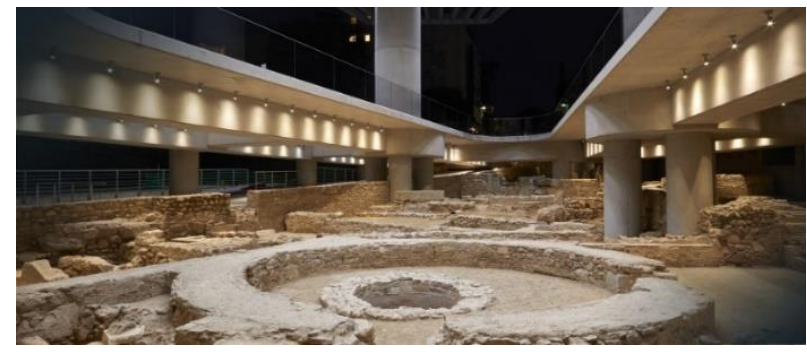

Şekil 4. Akropolis Müzesi'nin altındaki arkeolojik buluntular (URL-2, 2020)

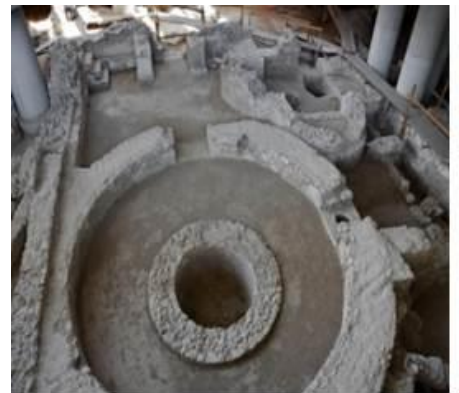

Şekil 5. Üç nişli oda ve E yapısının dairesel kule holü, MS 6. yy başı (URL-2, 2020)

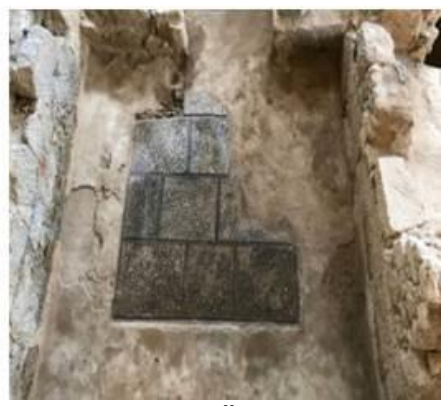

Şekil 6. Evin andronu, MÖ 5. yy (URL-2, 2020) 


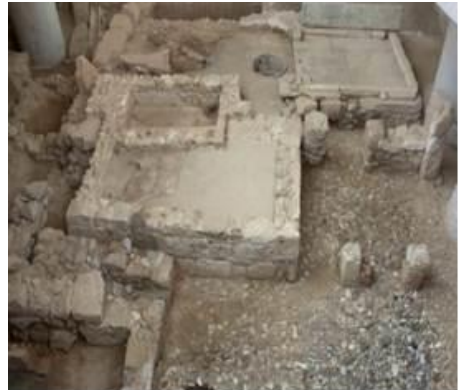

Şekil 7. Küçük bir özel hamam kalıntısı, MS 2. yy (URL-2, 2020)

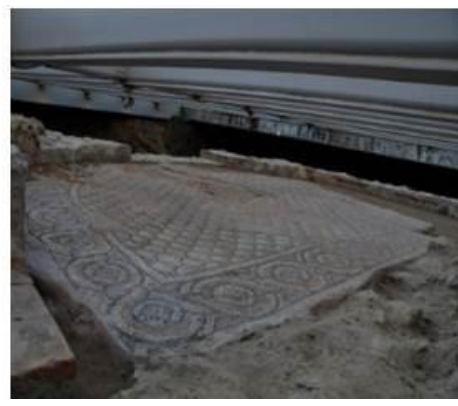

Şekil 8. Z binası girişinin mozaik zemini, MS 5. yy ortası (URL-2, 2020)
Antakya Müze Oteli, Roma İmparatorluğu döneminde dünyanın dördüncü gelişmiş şehri olarak bilinen Antakya'da yer almaktadır. Otel, Hıristiyanlar için önemli yeri olan St. Pierre Kilisesi'ne çok yakın bir yerde bulunmaktadır. 2009 yılında, bir otel inşa etmek isteyen bir yatırımcı, otel projesi için bu alanda kazıya başlamıştır. Kazıya başlandığında alanda önemli arkeolojik kalıntılar bulunmuştur. Kültür ve Tabiat Varlıklarını Koruma Kurulu yatırımcıdan arkeolojik kazı başlatmasını istemiştir. Kazı sürecinde çalışmak üzere arkeologlar, sanat tarihçileri, restoratörler ve mimarlardan oluşan bir uzman grubu oluşturulmuştur. Uzman grup tarafından ortaya çıkarılan arkeolojik kalıntılar, alanda otel inşasını imkânsız hale getirmiştir (Şekil 9). Bu durum, geleneksel otel tipolojisini bozarak, arkeolojik eserlerin sergileneceği bir kamu müzesinin otele entegre edilme fikrini ortaya koymuştur (URL-3, 2020).
Geleneksel otel tasarımında çoğunlukla zemin katta yer alan restoran, gece kulübü, spor salonu ve yüzme havuzu gibi ortak alanlar çatı katına yerleştirilmiştir. Alt katta, buluntuların yaklaşık $15 \mathrm{~m}$ yukarısında, çelik kirişlerle bir ızgara yapısı inşa edilmiştir. Prefabrik otel odası modülleri, bu sistemin üzerine aralıklarla yerleştirilmiştir. Odaların hemen altında, arkeolojik kalıntıların yaklaşık $10 \mathrm{~m}$ yukarısında, otel lobisi tasarlanmıştır. Her katta devam eden mekanlar arası akışkanlık ve geçirgenlik ile arkeolojik sit alanına çeşitli görsel bağlantılar sağlamıştır (URL-3, 2020). Kalıntıların birkaç metre üzerinde, yapıyı şehir merkezine bağlayan bir arkeoloji müzesi tasarlanmıştır. Müzede asma köprü ve rampalardan oluşan sirkülasyon ağı kalıntılara göre düzenlenmiştir. Müzede ziyaretçiler tarafından herhangi bir fiziksel temas olmaksızın kalıntıların yakın mesafeden izlenebilmesi sağlanmiştır (URL-3, 2020).
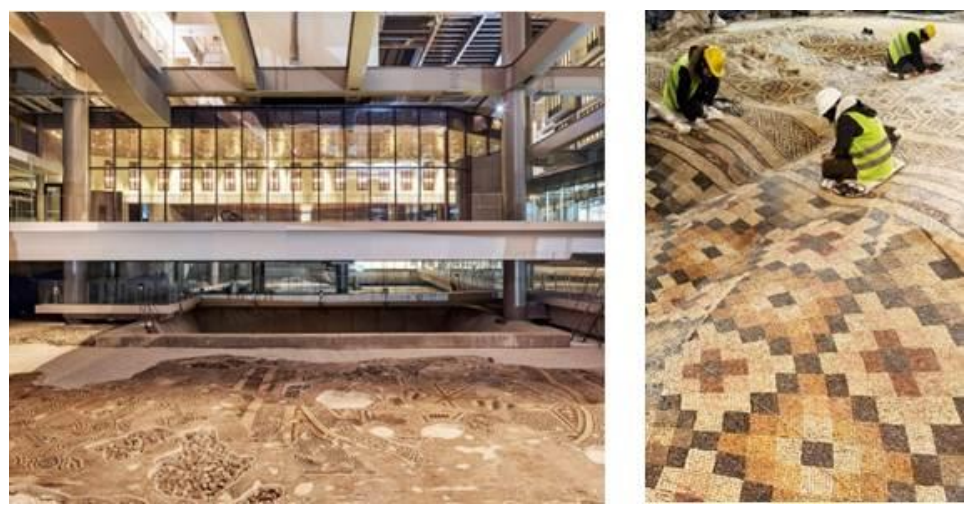

Şekil 9. Antakya Müze Oteli (URL-3, 2020)

Otelin altında bulunan Necmi Asfuroğlu Arkeoloji Müzesi'nde Roma Dönemi'ne ait, çeşitli büyüklükteki taban mozaikleri yerinde sergilenmektedir. Müze bu özelliğinden dolayı dünyadaki sayılı örneklerden biridir (URL-4, 2020). Mozaikler arasında Pegasus Mozaiği olarak adlandırılan MS 2. yy Roma Dönemi villasına ait taban mozaiği bulunmaktadır (Şekil 10). Mozaik dört panele ayrılmıştır. Mozaiğin ana panelinde mitolojik kanatlı at Pegasus ve onu bir törene hazırlayan üç peri ana figürleri bu- lunmaktadır. Ana panelin altında yer alan diğer üç panelde ise ilham perilerinden biri olan Kalliope ile yazar Hesiodos'un karşılaşması anlatılmaktadır. "Dünyanın en büyük tek parça mozaiği" olarak kabul edilen, $1050 \mathrm{~m}^{2}$ büyüklüğündeki mozaik Pegasus Mozaği'nin hemen yanında bulunmaktadır (URL-4, 2020).

Kazılarda 5. yüzyıldan kalan hamamlar ortaya çıkmıştır (Şekil 11). Bu hamamlar Romalıların masaj ve yemek keyfi yapmak için toplandıkları önemli sosyal 
mekanlarındandır. Hamam sakinleri ılık ve soğuk su odalarında (Tepidarium ve Frigidarium) bir araya gelerek sosyalleşiyorlardı (URL-5,2020).

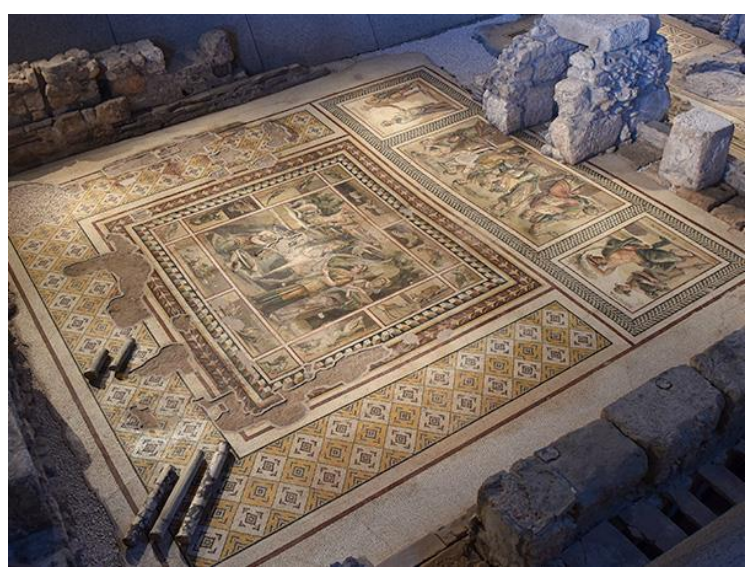

Şekil 10. Pegasus Mozaiği (URL-5,2020)
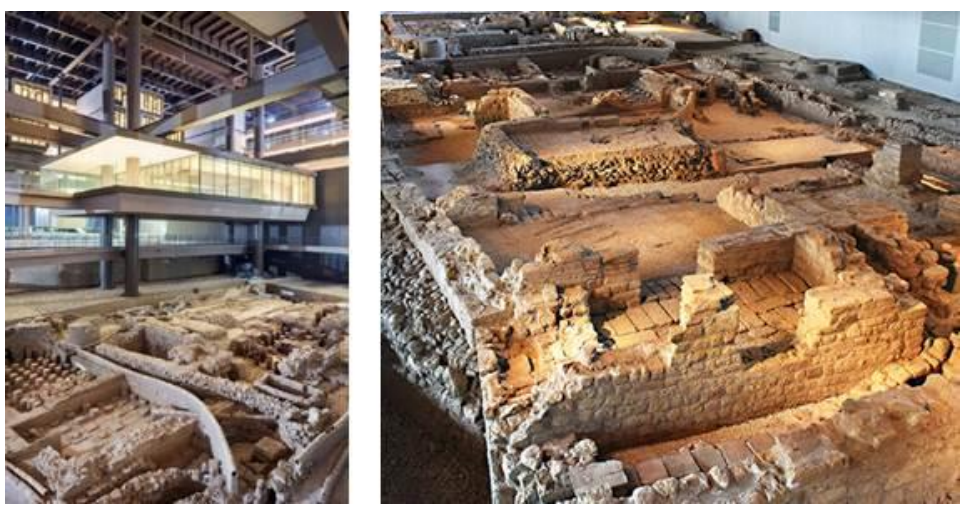

Şekil 11. Roma Hamamları (URL-5, 2020)

2008 yılında, Antalya Büyükşehir Belediyesi tarafından 2005 yılında düzenlenen Doğu Garajı ve Halk Pazarı yarışmasının inşaat kazıları başlandığında, alanda Roma dönemine ait Nekropol keşfedilmiştir. Sürpriz olarak ortaya çıkan nekropol, projeyi tamamen değiştirmiştir. Bunun üzerine koruma prensipleriyle bir Nekropol Müzesi tasarlanmıştır. Müze, arkeolojik kalıntıları doğal etmenlerden koruyan bir örtü olarak tasarlanmıştır (Şekil 12). Ayrıca, müze Nekropol boyunca gezinmeyi sağlayan yürüyüş yollarına ve galeri mekanlarına sahip olacak şekilde kurgulanmıştır (URL-6, 2020). Müzenin üst örtüsüne ait taşıyıcılar alanda bulunan kalıntılara zarar vermeyecek şekilde yerleştirilmiştir. Nekropol alanının çelik konstrüksiyon görüntüsü yerine yeşil bir çatı görüntüsü oluşması için çatısı bitki ile kaplanmıştır (URL-8, 2020). Kentsel bellekte önemli bir yere sahip olan Doğu Garajı
Pazarı, Antalya Kültür ve Ticaret Merkezi ile yeniden canlandırılmak istenmiştir (URL-7, 2020). Antalya Doğu Garajı Kültür ve Ticaret Merkezi'nde festival çarşısı, çok katlı pazar yeri, konser ve tiyatro salonu, yeme içme alanları bulunmaktadır. Beş katlı kompleksin ilk iki katında pazar yeri, 3. ve 4. katlarında festival çarşısı, en üst katta ise yeme içme alanları yer almaktadır. Antalya Kültür ve Ticaret Merkezi'nde kültürel ve sanatsal organizasyonların yanı sıra geleneksel çarşı kültürünün yaşatılması hedeflenmektedir. Komplekste 680 kişilik bir tiyatro salonu, Antalya Şehir Konservatuvarına ait 20 derslik, sanat galerileri, prova stüdyoları ve çeşitli atölyeler bulunmaktadır (URL-8, 2020). 

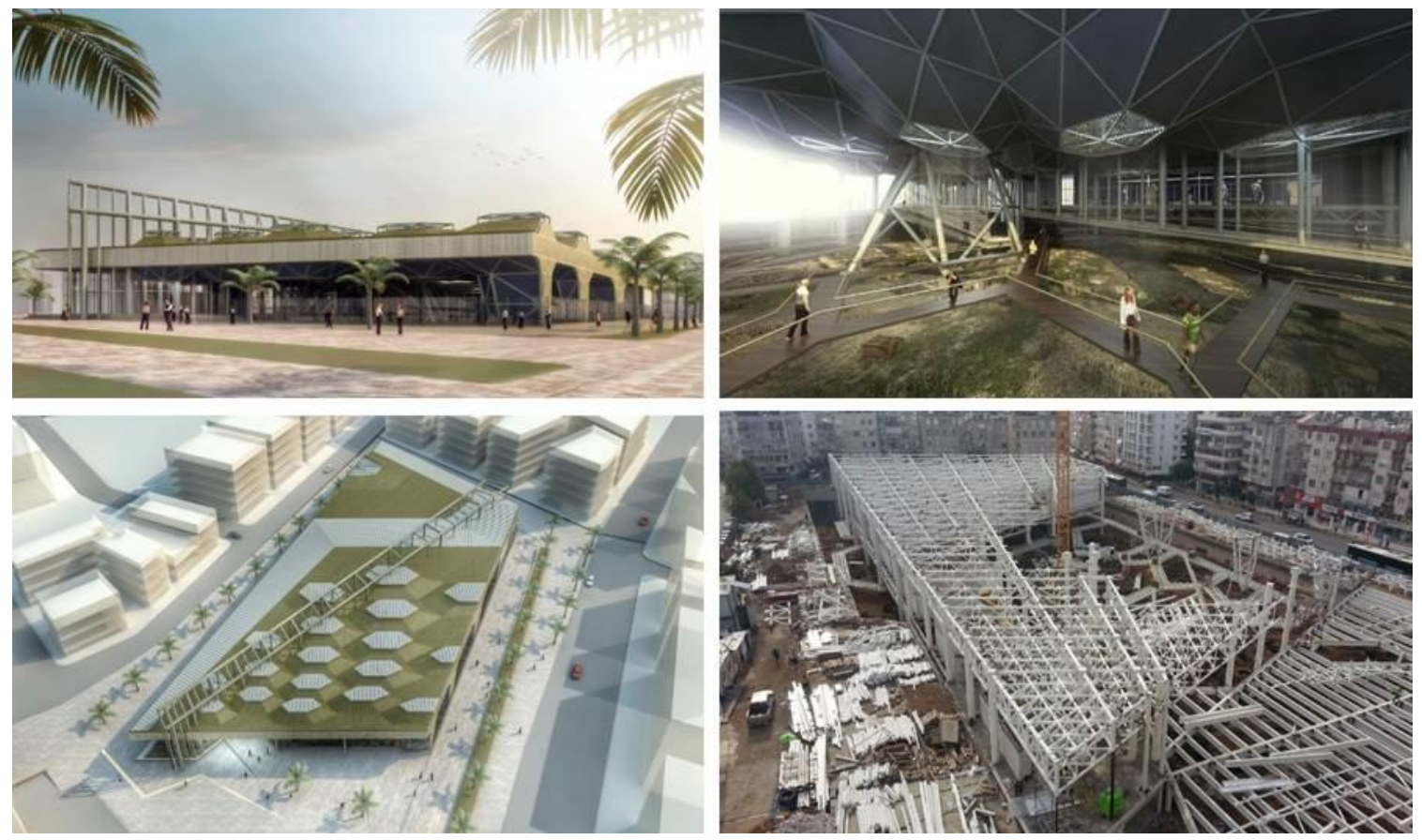

Şekil 12. Antalya Nekropol Alanı Kültür ve Ticaret Merkezi Projesi (URL-6, 2020)

Antalya Nekropol Alanı Kültür ve Ticaret Merkezi, Tarihi ve Kültürel Mirası Koruma Proje ve Uygulamalarını Özendirme Yarışması'nda 2018 Yılı Metin Sözen Koruma Büyük Ödülü’nü hak etmiştir. Proje, arkeolojik mirasın çağdaş çözümlerle kent hayatı içine entegre edilen tasarım anlayışı ve kent içindeki koruma-gelişim anlayışının dengeli bir biçimde kurulduğu için bu ödüle değer bulunmuştur (URL-7, 2020). Bu projeyle birlikte hem kentte yaşayanlar hem de turizm açısından bir çekim noktası oluşturulmuştur. Nekropol alanında ortaya çıkarılan mezarlar 3 tipte gruplandırılmıştır (Şekil 13). Bu mezar tipleri; sandık mezarlar, khamosorion mezarlar ve dromoslu oda mezarlardır (Tosun ve Akman, 2011).
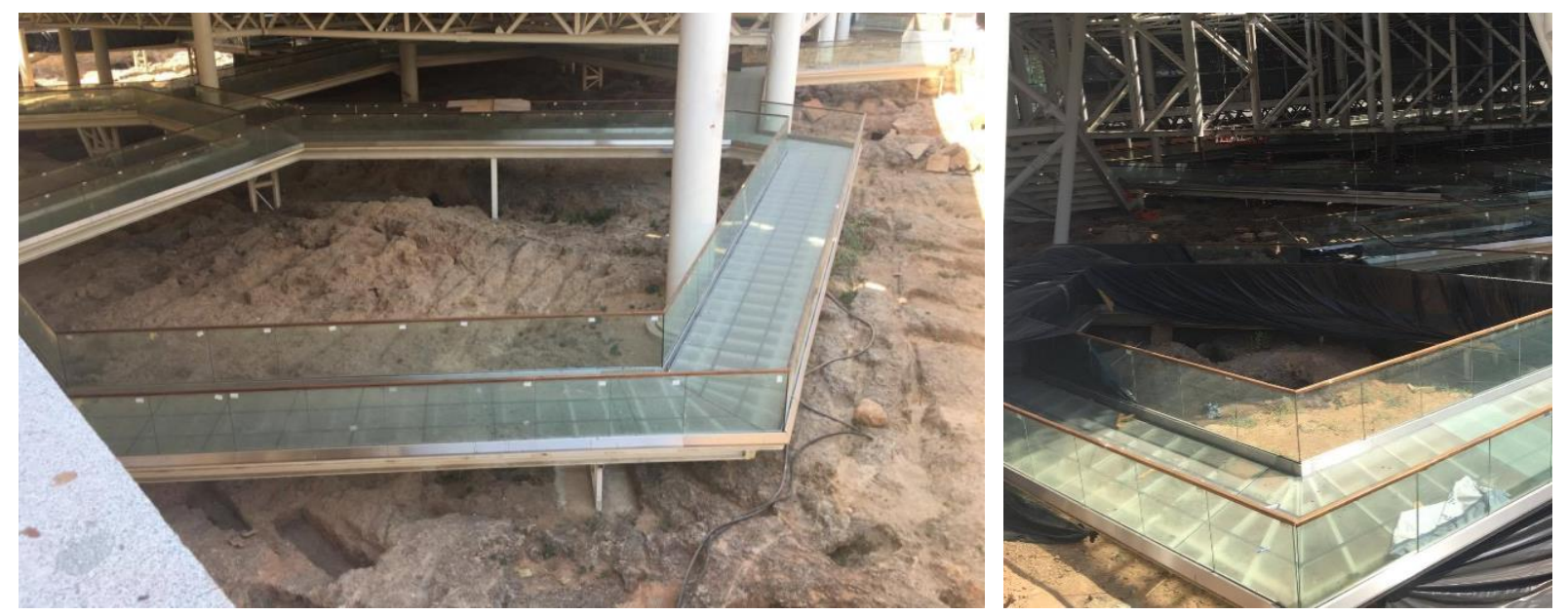

Şekil 13. Nekropol Alanı (Göküz, 2020)

Çalışmada literatür aşamasından sonra her üç yapının da mimari projeleri incelenmiştir. Daha sonra yapılar tasarım kriterleri açısından 4 ana başlık (işlev, uygun ve sürdürülebilir teknoloji, kalıntılar ve alan arasındaki ilişki, sosyal ve toplumsal intiyaçlara cevap vermek) altında ele alınmıştır. Tasarım kriterleri konu ile ilgili Ertosun (2012)'un yaptığı çalışmadan ve yurtdışında benzer amaçlarla yapılmış çalışmalardan yorumlanarak tablo haline getirilmiştir. Tablo 4 ana başı ık altında 25 alt başlığa ayrılmıştır. Elde edilen 25 tasarım kriterleri tablo 
oluşturularak seçilen üç yapıya uygun olup olmadığına göre, Akdeniz Üniversitesi Mimarlık Fakültesi'ndeki öğretim elemanlarından oluşan 10 kişilik uzmana doldurtulurmuştur. Uzmanlar mimarlık, iç mimarlık, peyzaj mimarlığı, şehir bölge planlama ve endüstri ürünleri tasarımı gibi farklı disiplinlerden seçilmiştir. Uzmanların verdikleri cevaplara göre her kriter için yarıdan fazla ortak verilen cevap tabloya işlenmiştir.

\section{BULGULAR}

Atina Yeni Akropol Müzesi, Antakya Müze Oteli, Antalya Nekropol Alanı Kültür ve Ticaret Merkezi, Ertosun (2012)'un çalışmasında bulunan arkeolojik alanı koruyan yapılar için gerekli tasarım kriterlerine göre incelenmiştir. Tasarım kriterleri; işlev, uygun ve sürdürülebilir teknoloji, kalıntılar ve alan arasındaki ilişki, sosyal ve toplumsal intiyaçlara cevap vermek olarak alt başlıklara ayrılarak incelenmiştir.

\section{Atina Yeni Akropol Müzesi}

İşlev

- Atina Yeni Akropol Müzesi'nde devam eden kazılar bulunmadığı için devam eden kazıların korunmasıyla ilgili bir durum bulunmamaktadır.

- Yapıda güvenlik ve kalıntıların algılanması için uygun iç sirkülasyon sağlanmıştır. Kalıntıların ve ziyaretçilerin güvenliği ve emniyetini sağlanmıştır. Sunuma ve yoruma katkıda bulunmuştur.

\section{Uygun ve Sürdürülebilir Teknoloji}

- Atina Yeni Akropol Müzesi kalıntıların üst katmanında müze bulunduğundan gelecekteki genişletmeler ve kaldırmalar durumunda uyarlanabilir değildir.

- Atina Yeni Akropol Müzesi klima yoluyla sıcaklık ve nem üzerinde kontrol sağlamaktadır.

- Yapı orijinal kalıntılarla uyumlu değildir. Orijinal kalıntılardan ayırt edilebilir bir tasarım yapılmıştır. Tamamen tersine çevrilebilir ve daha fazla hasara neden olmayan çözümler kullanılmıştır.

\section{Kalıntılar ve Alan Arasındaki İlişki}

- Atina Yeni Akropol Müzesi'nde müdahaleler olabildiğince buluntulara az zarar verecek şekilde tutulmuştur.

- Atina Yeni Akropol Müzesi korunan alanın altındaki veya çevresindeki kalıntılara zarar vermemektedir. Varsayımlarla kalıntıları tamamlamaya ve yanlış yönlendirmeye çalışmamaktadır. Arkeolojik kanıtların ve içsel değerlerin kaybolmasına neden olmamaktadır.
- Yapıda hem doğal hem de insan yapımı öğeleriyle alana saygı duyulmamıştır. Korunan alan ile geri kalanı arasındaki ilişkiyi bozulmuştur.

- Atina Yeni Akropol Müzesi'nde kalıntılar arasında eşitsizlik yaratılmamıştır. Bütün kalıntılar aynı önemde görülerek bir kurgulama yapılmıştır.

\section{Sosyal ve Toplumsal İhtiyaçlara Cevap Vermek}

- Yapı araştırma sonuçlarının sunum, yorumlama ve dağıtımına katkıda bulunmaktadır.

- Kalıntıların korunması ve sunumu arasında bir denge sağlanmıştır.

- Ziyaretçilerin kalıntıları rahat ve kolay anlamasını sağlanmıştır.

\section{Antakya Müze Oteli}

İşlev

- Antakya Müze Otel'de devam eden kazılar bulunmadığı için devam eden kazıların korunmasıyla ilgili bir durum bulunmamaktadır.

- Yapıda güvenlik ve kalıntıların algılanması için uygun iç sirkülasyon sağlanmıştır. Kalıntıların ve ziyaretçilerin güvenliği ve emniyetini sağlanmıştır. Sunuma ve yoruma katkıda bulunmuştur.

\section{Uygun ve Sürdürülebilir Teknoloji}

- Antakya Müze Oteli kalıntıların üst katmanında otel odaları bulunduğundan gelecekteki genişletmeler ve kaldırmalar durumunda uyarlanabilir değildir.

- Otel, klima yoluyla sıcaklık ve nem üzerinde kontrol sağlamaktadır.

- Yapı orijinal kalıntılarla uyumlu değildir. Orijinal kalıntılardan ayırt edilebilir bir tasarım yapılmıştır. Tamamen tersine çevrilebilir ve daha fazla hasara neden olmayan çözümler kullanılmıştır.

\section{Kalıntılar ve Alan Arasındaki İlişki}

- Antakya Müze Otel'de müdahaleler olabildiğince buluntulara az zarar verecek şekilde tutulmuştur.

- Antakya Müze Otel korunan alanın altındaki veya çevresindeki kalıntılara zarar vermemektedir. Varsayımlarla kalıntıları tamamlamaya ve yanlış yönlendirmeye çalışmamaktadır. Arkeolojik kanıtların ve içsel değerlerin kaybolmasına neden olmamaktadır.

- Yapıda hem doğal hem de insan yapımı öğeleriyle alana saygı duyulmamıştır. Korunan alan ile geri kalanı arasındaki ilişkiyi bozulmuştur. 
- Antakya Müze Otel'de kalıntılar arasında eşitsizlik yaratılmıştır. Bazı kalıntılar daha fazla ön plana çıkarılacak şekilde bir kurgulama yapılmıştır.

\section{Sosyal ve Toplumsal İhtiyaçlara Cevap Vermek}

- Yapı araştırma sonuçlarının sunum, yorumlama ve dağıtımına katkıda bulunmaktadır.

- Kalıntıların korunması ve sunumu arasında bir denge sağlanmıştır.

- Ziyaretçilerin kalıntıları rahat ve kolay anlamasını sağlanmıştır.

\section{Antalya Nekropol Alanı Kültür ve Ticaret Merkezi İşlev}

- Antalya Nekropol Alanı Kültür ve Ticaret Merkezi'nde nekropol alanındaki mezarlar üzerinde yabancı otlar bulunmaktadır. Bu alan çevre koşullarına ve biyolojik tehditlere karşı korunmada eksik kalmıştır.

- Antalya Nekropol Alanı Kültür ve Ticaret Merkezi'nde devam eden kazılar bulunmadığı için devam eden kazıların korunmasıyla ilgili bir durum bulunmamaktadır.

- Yapıda güvenlik ve kalıntıların algılanması için uygun iç sirkülasyon sağlanmıştır. Kalıntıların ve ziyaretçilerin güvenliği ve emniyetini sağlanmıştır. Sunuma ve yoruma katkıda bulunmuştur.

\section{Uygun ve Sürdürülebilir Teknoloji}

- Antalya Nekropol Alanı'nın cepheleri açık olduğu için havalandırma yoluyla sıcaklık ve nem üzerinde kontrol sağlanmaktadır.

- Yapı orijinal kalıntılarla uyumlu değildir. Orijinal kalıntılardan ayırt edilebilir bir tasarım yapılmıştır. Tamamen tersine çevrilebilir ve daha fazla hasara neden olmayan çözümler kullanılmıştır.

\section{Kalıntılar ve Alan Arasındaki İlişki}

- Antalya Nekropol Alanı Kültür ve Ticaret Merkezi'nde müdahaleler olabildiğince buluntulara az zarar verecek şekilde tutulmuştur.
- Antalya Nekropol Alanı Kültür ve Ticaret Merkezi korunan alanın altındaki veya çevresindeki kalıntılara zarar vermemektedir. Varsayımlarla kalıntıları tamamlamaya ve yanlış yönlendirmeye çalışmamaktadır. Arkeolojik kanıtların ve içsel değerlerin kaybolmasına neden olmamaktadır.

- Yapı hem doğal hem de insan yapımı öğeleriyle alana saygı duyulmamıştır. Korunan alan ile geri kalanı arasındaki ilişkiyi bozulmuştur.

- Antalya Nekropol Alanı Kültür ve Ticaret Merkezi'nde kalıntılar arasında eşitsizlik yaratılmamıştır. Bütün kalıntılar aynı önemde görülerek bir kurgulama yapılmıştır.

\section{Sosyal ve Toplumsal İhtiyaçlara Cevap Vermek}

- Yapıda araştırma sonuçlarının sunum, yorumlama ve dağıtımına katkıda bulunmaktadır.

- Kalıntıların korunması ve sunumu arasında bir denge sağlanmıştır.

- Ziyaretçilerin kalıntıları rahat ve kolay anlamasını sağlanmıştır.

Kent içi arkeolojik alanların kent yaşamına katılıp, kent kullanıcısının alanla ilişkisinin kurulması kent mekanlarının uygun kullanımı açısından gerekliliği ortadadır. Kent kullanıcısının kent yaşamı içerisinde arkeolojik alanlarla karşılaşması sağlanmalıdır. Bu durumda öncelikli amaç koruma olmalıdır. Kentsel algıyı arttıracak mekanlar oluşturulmalıdır. Hem koruma hem de sergileme ile kentte yaşayan insanların alanla ilişkilendirilmesi mümkün olur. Kentsel arkeolojik alanların korunarak ve işlevlendirilerek sonraki nesillere aktarılmasıyla hem kente hem de ülkeye kültürel ve ekonomik anlamda katkısı olur.

Arkeolojik alanlarda koruyucu yapılar için tasarım kriterleri; dünyadan Atina Yeni Akropol Müzesi, ülkemizden ise Antakya Müze Otel ile Antalya Nekropol Alanı Kültür ve Ticaret Merkezi ele alınarak incelenmiştir. Ertosun (2012)'un çalışmasında bulunan arkeolojik alanlarda koruyucu yapılar için tasarım kriterleri; işlev, uygun ve sürdürülebilir teknoloji, kalıntılar ve alan arasındaki ilişki, sosyal ve toplumsal intiyaçlara cevap vermek olarak alt başlıklara ayrılarak 3 mekanda incelenmiştir (Tablo 1). 
Tablo 1. Arkeolojik alanlarda koruyucu yapılar için tasarım kriterleri (tasarım kriterleri Ertosun (2012)'un çalışmasından alınmıştır.)

\begin{tabular}{|c|c|c|c|}
\hline $\begin{array}{l}\text { Arkeolojik Alanlarda Koruyucu Yapılar İçin Tasa- } \\
\text { rım Kriterleri }\end{array}$ & $\begin{array}{l}\text { Atina Yeni Ak- } \\
\text { ropol Müzesi }\end{array}$ & $\begin{array}{l}\text { Antakya Müze } \\
\text { Oteli }\end{array}$ & $\begin{array}{l}\text { Antalya Nekropol } \\
\text { Alanı Kültür ve Ti- } \\
\text { caret Merkezi }\end{array}$ \\
\hline \multicolumn{4}{|l|}{ İşlev } \\
\hline $\begin{array}{l}\text { Kalıntıları çevre koşullarına ve biyolojik tehditlere } \\
\text { karşı korumak }\end{array}$ & $\checkmark$ & $\checkmark$ & - \\
\hline Devam eden kazıları korumak & - & - & - \\
\hline $\begin{array}{l}\text { Güvenlik ve kalıntıların algılanması için uygun iç sir- } \\
\text { külasyon sağlamak }\end{array}$ & $\checkmark$ & $\checkmark$ & $\checkmark$ \\
\hline $\begin{array}{l}\text { Kalıntıların ve ziyaretçilerin güvenliği ve } \\
\text { emniyetini sağlamak }\end{array}$ & $\checkmark$ & $\checkmark$ & $\checkmark$ \\
\hline Sunuma ve yoruma katkıda bulunmak & $\checkmark$ & $\checkmark$ & $\checkmark$ \\
\hline \multicolumn{4}{|l|}{ Uygun ve Sürdürülebilir Teknoloji } \\
\hline $\begin{array}{l}\text { Gelecekteki genişletmeler ve kaldırmalar durumunda } \\
\text { uyarlanabilir olmak }\end{array}$ & - & - & $\checkmark$ \\
\hline $\begin{array}{l}\text { Havalandırma yoluyla sıcaklık ve nem üzerinde kont- } \\
\text { rol sağlamak }\end{array}$ & - & - & $\checkmark$ \\
\hline $\begin{array}{l}\text { Klima yoluyla sıcaklık ve nem üzerinde kontrol sağla- } \\
\text { mak }\end{array}$ & $\checkmark$ & $\checkmark$ & - \\
\hline $\begin{array}{l}\text { Su tutmayan, kendi kendini temizleyen, yarı saydam } \\
\text { vb. gibi malzemelerden yararlanılarak daha güçlü ve } \\
\text { daha hafif çözümleri kullanmak }\end{array}$ & $\checkmark$ & $\checkmark$ & $\checkmark$ \\
\hline Kendi kendine yeten, çevre dostu tasarım kullanmak & - & - & - \\
\hline Orijinal kalıntılarla uyumlu olmak & - & - & - \\
\hline Orijinal kalıntılarla ayırt edilebilir olmak & $\checkmark$ & $\checkmark$ & $\checkmark$ \\
\hline $\begin{array}{l}\text { Tamamen tersine çevrilebilir ve daha fazla hasara ne- } \\
\text { den olmayan çözümler kullanmak }\end{array}$ & $\checkmark$ & $\checkmark$ & $\checkmark$ \\
\hline \multicolumn{4}{|l|}{ Kalıntılar ve Alan Arasındaki Ílişki } \\
\hline Müdahaleleri minimum düzeyde tutmak & $\checkmark$ & $\checkmark$ & $\checkmark$ \\
\hline $\begin{array}{l}\text { Korunan alanın altındaki veya çevresindeki kalıntılara } \\
\text { zarar vermemek }\end{array}$ & $\checkmark$ & $\checkmark$ & $\checkmark$ \\
\hline $\begin{array}{l}\text { Hem doğal hem de insan yapımı öğeleriyle alana saygı } \\
\text { duymak ve gerçekliği ve ruhu yorumlamak }\end{array}$ & - & - & - \\
\hline $\begin{array}{l}\text { Varsayımlarla kalıntıları tamamlamaya ve yanlış yön- } \\
\text { lendirmeye çalışmamak }\end{array}$ & $\checkmark$ & $\checkmark$ & $\checkmark$ \\
\hline $\begin{array}{l}\text { Korunan alan ile geri kalanı arasındaki ilişkiyi bozma- } \\
\text { mak }\end{array}$ & - & - & - \\
\hline $\begin{array}{l}\text { Arkeolojik kanıtların ve içsel değerlerin kaybolmasına } \\
\text { neden olmamak }\end{array}$ & $\checkmark$ & $\checkmark$ & $\checkmark$ \\
\hline Kalıntılar arasında eşitsizlik yaratmamak & $\checkmark$ & - & $\checkmark$ \\
\hline \multicolumn{4}{|l|}{ Sosyal ve Toplumsal İhtiyaçlara Cevap Vermek } \\
\hline $\begin{array}{l}\text { Araştırma sonuçlarının sunum, yorumlama ve dağıtı- } \\
\text { mına katkıda bulunmak }\end{array}$ & $\sqrt{ }$ & $\checkmark$ & $\sqrt{ }$ \\
\hline $\begin{array}{l}\text { Yapı içinde ziyaretçilere diğer tesis ve hizmetleri sun- } \\
\text { mak }\end{array}$ & $\checkmark$ & $\checkmark$ & $\checkmark$ \\
\hline $\begin{array}{l}\text { Hasar riskini öngörerek aşııı yüklenmiş turizmi kontrol } \\
\text { etmek ve ziyaretçiler tarafından yapılan kirliliği önle- } \\
\text { mek }\end{array}$ & $\checkmark$ & $\checkmark$ & $\checkmark$ \\
\hline $\begin{array}{l}\text { Kalıntıların korunması ve sunumu arasında bir denge } \\
\text { sağlamak }\end{array}$ & $\checkmark$ & $\checkmark$ & $\checkmark$ \\
\hline $\begin{array}{l}\text { Ziyaretçilerin kalıntıları rahat ve kolay anlamasını } \\
\text { sağlamak }\end{array}$ & $\checkmark$ & $\checkmark$ & $\checkmark$ \\
\hline
\end{tabular}




\section{SONUÇLAR}

Antalya Nekropol Alanı Kültür ve Ticaret Merkezi'nde nekropol alanındaki mezarlar üzerinde yabancı otlar bulunmaktadır. Bu alanı çevre koşullarına karşı korumak için üst örtü sistemi geliştirilmiş, fakat biyolojik tehditlere karşı korunmada eksik kalınmıştır. Antalya Nekropol Alanı Kültür ve Ticaret Merkezi'ndeki durumun tersine, Atina Yeni Akropol Müzesi ve Antakya Müze Oteli kalıntıları çevre koşullarına ve biyolojik tehditlere karşı koruyabilmiştir.

İncelenen üç mekanda da devam eden kazılar bulunmadığı için devam eden kazıların korunmasıyla ilgili bir durum bulunmamaktadır.

Tüm yapılarda güvenlik ve kalıntıların algılanması için uygun iç sirkülasyon sağlanmıştır. Ziyaretçiler yapı içerisinde dolaşırken, herhangi bir fiziksel temas olmaksızın kalıntıları yakın mesafeden izleyebilmesi sağlanmıştır. Kalıntıların ve ziyaretçilerin güvenliği ve emniyetini sağlanmıştır. Sunuma ve yoruma katkıda bulunmuştur.

Atina Yeni Akropol Müzesi kalıntıların üst katmanında müze yapısı devam ettiğinden gelecekteki genişletmeler ve kaldırmalar durumunda uyarlanabilir değildir. Atina Yeni Akropol Müzesi'ne benzer bir durumu bulunan Antakya Müze Oteli'nde de kalıntıların üst katmanında otel odaları bulunduğundan gelecekteki genişletmeler ve kaldırmalar durumunda uyarlanabilir değildir. Ancak, Antalya Nekropol Alanı Kültür ve Ticaret Merkezi'nin nekropol alanı gelecekteki genişletmeler ve kaldırmalar durumunda uyarlanabilirdir.

Hem Atina Yeni Akropol Müzesi hem de Antakya Müze Oteli klima yoluyla sıcaklık ve nem üzerinde kontrol sağlamaktadır. Antalya Nekropol Alanı'nda ise sadece üst örtü sistemi olup cepheleri açık olduğu için havalandırma yoluyla sıcaklık ve nem üzerinde kontrol sağlanmaktadır.

İncelenen üç mekanda kendi kendine yeten çevre dostu tasarım kullanılmamıştır. Yapılarda sürdürülebilir tasarım yaklaşımı bulunmamaktadır.

Yapılar orijinal kalıntılarla uyumlu değildir. Orijinal kalıntılardan ayırt edilebilir bir tasarım yapılmıştır. Böylelikle hangisinin arkeolojik kalıntı hangisinin sonradan eklenmiş olduğu rahatıkla anlaşılabilmektedir. Tamamen tersine çevrilebilir ve daha fazla hasara neden olmayan çözümler kullanılmıştır.

İncelenen üç mekanda korunan alanın altındaki veya çevresindeki kalıntılara zarar vermemektedir. Müdahalelerin olabildiğince en az seviyede tutulması sağlanmıştır. Tasarım aşamalarında taşıyıcıların yerleri kalıntılara zarar vermeyecek şekilde özenle seçilmiştir. Varsayımlarla kalıntıları tamamlamaya ve yanlış yönlendirmeye çalışmamaktadır. Böylelikle arkeolojik kanıtların ve içsel değerlerin kaybolmasına neden olmamaktadır. Yapıya gelen ziyaretçilerin yanlış bilgilendirilmesinin önüne geçilmeye çalışıımıştır.

Tüm yapılarda hem doğal hem de insan yapımı öğeleriyle alana saygı duyulmamıştır. Korunan alan ile geri kalanı arasındaki ilişkiyi bozulmuştur.

Atina Yeni Akropol Müzesi ile Antalya Nekropol Alanı Kültür ve Ticaret Merkezi'nde kalıntılar arasında eşitsizlik yaratılmamıştır. Bütün kalıntılar aynı önemde görülerek bir kurgulama yapılmıştır. Antakya Müze Otel'de ise kalıntılar arasında eşitsizlik yaratılmıştır. Bazı kalıntılar daha fazla ön plana çıkarılacak şekilde bir kurgulama yapılmıştır.

İncelenen üç mekan da araştırma sonuçlarının sunum, yorumlama ve dağıtımına katkıda bulunmaktadır. Hasar riskini öngörerek aşırı yüklenmiş turizmi kontrol etmek ve ziyaretçiler tarafından yapılan kirliliği önlemektedir. Kalıntıların korunması ve sunumu arasında bir denge sağlanmıştır. Ziyaretçilere alandaki arkeolojik kalıntıları sergilerken ön koşul kalıntıların korunması olmuştur. Ziyaretçilerin kalıntıları rahat ve kolay anlamasını sağlanmıştır. Bunun için gerekli bilgilendirme levhaları alanın asıl öznesi olan arkeolojik kalıntıların önüne geçmeyecek şekilde tasarlanmıştır.

\section{KAYNAKLAR}

Akkurt, H.B. (2010). Atina'da Çağdaş Bir Kültür Tapınağı; Yeni Akropol Müzesi. Ege Mimarlık. (74): 28-32.

Demirdağ, M.F. (2017). Ankara/Altındağ İlçesi Ulus Mevkii'nde Bulunan Antik Roma Tiyatrosu. Uluslararası Amisos Dergisi 2(3):11-23.

Ertosun, A.I. (2012). Evaluation of Protective Structure in Archaeological Sites for In Situ Conservation of Architectural Remains and Artifacts, Master Thesis, The Graduate School of Natural and Applied Sciences of Middle East Technical University.

ICOMOS (2008). Kültürel miras alanların algılanması ve sunumu tüzüğü. http://www.icomos.org.tr/ Dosyalar/ICOMOSTR_en0066198001536912401.pdf, (Erişim tarihi: 08/09/2020).

Madran, E., Özgönül, N. (2011). Kültürel ve Doğal Değerlerin Korunması. TMMOB Mimarlar Odası yayınları, Ankara, $190 \mathrm{~s}$.

Sarfatij, H., Melli, P. (1999). Archaeology and the Town, Report on the Urban Archaeology in Europe, Europe Publishing, Strasbourg, 13-29.

Savrum-Kortanoğlu, M. (2007). Kent Uzamında Arkeoloji. Colloquium Anatolicum (16): 105-121.

Şener, Y.S. (2013). Arkeolojik Alanda Yapı Malzemelerinin Korunması: Temel Yaklaşımlar, Yöntem ve Uygulama Biçimleri, Orhan Bingöl'e 67. Yaş Armağanı, Ankara, 611-624. 
Tosun, A., Akman, A. (2011). Doğu Garajı-Halk Pazar Mevkii (Attaleia Nekropolü) Kurtarma Kazısı 2009 Yılı Çalışmaları. Müze Çalışmaları ve Kurtarma Kazıları Sempozyumu (19): 97-116.

URL-1 (2020). http://www.tschumi.com/projects/2/\# (Erişim tarihi: 01/08/2020).

URL-2 (2020). https://www.theacropolismuseum.gr/en/content/archaeological-excavation-beneath-acropolis-museum, (Erişim tarihi: 08/08/2020).

URL-3, (2020). https://emrearolat.com/project/the-museumhotel-antakya/ (Erişim tarihi: 12/08/2020).

URL-4 (2020). https://muze.gov.tr/muze-detay?Distld=MRK\&Sectionld=NAM01 (Erişim tarihi: $15 / 08 / 2020)$.

URL-5 (2020). http://www.themuseumhotelantakya.com/tr/the-museum/index-more.php (Erişim tarihi: 12/08/2020)
URL-6 (2020). https://erkalarchitects.com/portfolio-item/necropolis/ (Erişim tarihi: 19/08/2020).

URL-7 (2020). https://yapidergisi.com/erkal-mimarlika-metinsozen-koruma-buyuk-odulu/ (Erişim tarihi: 20/08/2020).

URL-8 (2020). https://antalyabugun.com/tr/news/dogu-garajikultur-merkezi-projesinde-kaba-insaat-bitti-49938.html (Erişim tarihi: 21/08/2020).

URL-9 (2020). https://www.archdaily.com/61898/new-acropolis-museum-bernard-tschumi-architects (Erişim tarihi: 03/09/2020).

Yıkıcı, A. (2010). Kentsel Arkeolojik Alanların Korunmasına Yönelik Planlama Yaklaşımları: Yenikapı Arkeolojik Alan Yönetim ve Yönlendirme Rehberi. Mimar Sinan Güzel Sanatlar Üniversitesi, Fen Bilimleri Enstitüsü, Yüksek Lisans Tezi, İstanbul. 